\title{
Sustainable Development of Human Resources Inspired by Chinese Philosophies: A Repositioning Based on François Jullien's Works
}

\section{Sybille Persson $^{1}$ and Paul Shrivastava ${ }^{2}$ \\ ${ }^{1}$ ICN Business School, France, and ${ }^{2}$ Concordia University, Canada}

ABSTRACT This paper provides a philosophical repositioning of human resource management (HRM) to further sustainable human resources development (HRD). We use a conceptual process, based on the work of French philosopher and Sinologist François Jullien. Despite its growing and diversified academic production, HRM research has become increasingly isolated from practice, from alternative views of human life, and from nature. This is at least partly due to its failure to self-question its Western centric roots. This paper describes some key conceptual innovations that deal with efficacy and 'vital nourishment' which are of particular interest for sustainable HRD. The question of how to feed life (or nourish it) in the workplace is illustrated by a gardening metaphor for managing human potential. In contrast to cross-cultural studies, this metaphor emerges from a dialogue between Western and Eastern philosophies, and offers alternative approaches to HRD based on some core insights from the Chinese tradition.

KEYWORDS isolation vs. connection, sustainable human resource development, traditional Chinese philosophies, West and East dialogue

\section{INTRODUGTION}

In this paper we offer a conceptual innovation to make human resource development (HRD) more sustainable within human resource management (HRM). As humans face increasing ecological challenges, growing economic inequality, and hunger and poverty, and employees face increasing stress, burnout, and employment insecurity, HRM needs to deepen its focus on sustainable approaches to address these challenges (Houtman, Jettinghoff, \& Cedillo 2007; Intergovernmental Panel on Climate Change, 2007; Rockström et al., 2009; Stern, 2008; World Federation for Mental Health, 2012). Although recent research in HRM has become increasingly strategic (Schuler \& Jackson, 2007), it does not apply its findings specifically to professionals (Rynes, 2007) and barely considers environmental and social issues (Jackson, Renwick, Jabbour, \& Muller-Camen, 
2011). This paper is an attempt to remedy this situation, with ideas that can move the field of HRM to become more sustainable in developing full human potential.

We use a conceptual process to question the HRM field at the theoretical level and focus next on HRD at the practical level. This conceptual process comes from a philosophical tradition called 'deconstruction' which means 'to uncover an object' to reveal its foundations and its working mechanisms (Rappin, 2008: 13). Deconstruction has already been used in organizational theory (Kilduff, 1993) based on Michel Foucault's work (Starkey \& McKinlay, 1997; Townley, 1993). In this article, instead of referring to Foucault, we use the works of François Jullien to question the Western conception of HRD. Jullien has been a Hellenist and Sinologist for the last thirty years, applying deconstructive methods to provide a critical view of Western philosophy.

We offer a critical reflection for HRD to make it more sustainable by welcoming relevant foundations of Chinese tradition in four steps. We begin by critiquing the increasing isolation of HRM from practice, from human communities, and from nature. Next, we explain the conceptual innovations by Jullien regarding efficiency, efficacy, and life processes. Jullien shows that Western rationality is static and technocratic, and unable to capture the true (vital) essence of life, which is flexible, organic, and non-static (Rappin, 2008). Next, we introduce the concept of managing human potential in organizations through an organic metaphor of gardening. Finally, we propose green avenues for HRM research through HRD practices. We conclude with some observations on the relevance of Chinese philosophies for the development of human resources.

\section{THE INGREASING ISOLATION OF HRM FROM PRACTICE, HUMAN LIFE, AND NATURE}

\section{HRM with Western Assumptions}

A Special Topic Forum of $A M \mathcal{J}$ dedicated to the management of human resources revealed the great divide between the academic and practitioner worlds. Even hard facts accumulated through evidence-based management (Rousseau, 2006) do not have the expected impacts on HRM practitioners (Rynes, Gulik, \& Brown, 2007). Academic and practitioner communities perceive different topics to be of importance to them. Journalists and consultants have become more successful in attracting practitioners to their writings compared to academic researchers (Rynes et al., 2007). HRM research is now deeply isolated from practice.

HRM is disconnected from human life because it has limited itself to concerns of increasing human performance and productivity within organizations (Dany, 2009; Godard \& Delaney, 2003; Janssens \& Steyaert, 2009). In mainstream HRM, functions are subordinated to the economic strategy of the firm both in matters of effectiveness that deal with meeting environmental demands, and also in matters of efficiency that deal with input and output ratios. Rynes, Gulik, and Brown (2007) 
state that 3 of the 10 most cited Academy of Management fournal (AMJ) articles dedicated to HRM since 1990 are based on productivity strategies (Becker \& Gerhart, 1996; Delery \& Doty, 1996; Huselid, 1995). Studies indicate that HRM systems have converged around productivity issues (Jackson et al., 2011), and lack serious engagement with environmental sustainability (Jackson \& Seo, 2010).

Regardless of theoretical orientation (resource based view, human capital theory, labor process theory, or behavioral perspective), the HRM field today remains closed from broad concerns about human life and human potential (Jackson \& Seo, 2010). It is concerned mainly with the instrumental use of humans in specific organizational settings, with narrow goals of enhancing economic productivity. It is not concerned with what it means to be human, what nourishes human life, and what fosters human potential.

Moreover, the HRM field separates humans from nature. With the desire to treat the human function like other functions in the firm (e.g., accounting, finance, marketing, information systems), HRM has disregarded the idea that humans are emotional, spiritual, and physical beings. It does not consider the Chinese body-mind-spirit model (Hwang, 2012: 22-24) where the physical self precedes the psychological self and the spiritual self in the course of life (Chen \& Bhikkhu, 2003).

We acknowledge that some management researchers resist reducing humans to resources, and accommodate humanism, moral concerns, or benevolence (Sims, Fineman, \& Gabriel, 1990; Steyeart \& Janssens, 1999; Tsoukas, 1994). Similarly, the HRM field as a whole, with its two sides, strategist and/or humanist (Dany, 2009), has not yet developed an encompassing and holistic conceptualization for HR (Fang, 2012). Especially, it exhibits a 'human-nature dualism' nurtured by a 'disembodied form of technological knowing conjoined with an egocentric organizational orientation' that is deeply embedded in most management studies (Purser, Park, \& Montuori, 1995: 1053).

Sandberg and Tsoukas (2011) describe the logic of practice to deal with the increasing practical irrelevance of management theories. Scholars, who think that it is possible to bridge the theory-practice gap, advocate for a practical rationality as an alternative to scientific rationality. They try to deal with the epistemological separation of subject-object (human versus the rest of the world) and the issue of subjectivity. However, they do not abandon Western rationality, which is the root source of the gap they are attempting to bridge. Even within a phenomenological perspective, they advocate 'being-in-the-world' (to face the separation of subjectobject) as the primordial mode of human engagement with the world. However, they stay anchored in the Western framework of identity (existential identity) within subjective rationality. They do not really leave the question of existing to grasp the question of living.

Existence is linked to anthropocentrism, the dominant paradigm of the West that perceives a fundamental dualism between organizations and the natural environment. Existence of human beings is seen as separated from the rest of the world. Living on the other hand is linked to ecocentrism, without separation between 
the human and non human world. Life cannot be reduced to humans. Ecocentrism instead of anthropocentrism appears as a competing paradigm that Purser et al. (1995) see as a useful stimulus for ecocentric theory development. However, neither Sandberg and Tsoukas (2011), nor Purser et al. (1995) have looked at Chinese philosophies as a potential resource for understanding the distinction between existing and living.

The deep foundations of Chinese philosophies (Chen \& Lee, 2008) and Chinese cultural and social psychology (Hwang, 2012) are especially relevant to HRD, because of the way they see humans' entangled connections to context, Confucian relationism and social exchange, and practical wisdom. This calls for us to explore 'the spirit of science' (Tsui, 2013) and question 'the Western academic hegemony [...] in all fields of social sciences' (Hwang, 2012: xiii) which is disconnected from other indigenous knowledge and cultures.

Under the Western view, human life as a form of capital (as an 'asset' or 'resource'), makes it difficult for HRM to grasp the central question of sustainability. True and enduring sustainability challenges the Western management concern of using scientific methods to propel economic and social performance (Shrivastava, Ivanaj, \& Persson, 2013).

\section{Opening a Door to Chinese Philosophies}

The question of (human) being linked to the issue of subjectivity is at the heart of Western philosophy. Based on another worldview, traditional Chinese thought rejects the dichotomy between subject and object (Fang, 2012). The question of subjectivity appears only in China through the influence of Indian philosophy, especially Buddhism (Mélès, 2009).

This original inseparability between subject and object is not only a core philosophical orientation but also a fundamentally different way to consider life and living as a unique sustainable process. The core concepts of Western philosophy (such as soul, being, knowledge, meaning, and rationality) are isolated from their natural and social environment. In fact, these Western concepts are very difficult to translate into Chinese words and are very different from Chinese philosophies, especially in the Daoist tradition: 'Daoism is a way of life and human existence in relation to the universe rather than simply an ethical or religious way of behaving' (Lee, Han, Byron, \& Fan, 2008: 85). That is why living 'is beyond meaning' (Jullien, 2007: 8). Since it is a question of 'living' (Daoist orientation) and not of 'existing' (phenomenologist orientation), it resists abstraction. This type of thinking does not separate thought from action, theory from practice, human beings from their environment.

However, analysis of thought at a fundamental level begins with language (Wenzel, 2010). China has a three thousand year textual tradition, with minimal European influence, and classic Chinese does not belong to the family of IndoEuropean languages. It does not work as Indo-European languages, which have 
constructed 'alphabetic civilizations' far from the natural environment (Abram, 1996). 'Iconic writing systems - those that employ pictographic, ideographic, and/or rebuslike characters - necessarily rely, to some extent, upon our original sensory participation with the enveloping natural field' (Abram, 1996: 138). This was different for the Greek language (which is the philosophical source of Western thought) through the emergence of the phonetic alphabet and associated letters.

In this paper, by using 'dialogue' between cultures (Chen \& Miller, 2010, 2011) rather than 'comparison', we abandon the Western research design of comparative cross-cultural studies. This approach is not sufficient because it ignores the sensemaking capacities of other cultures (Fang, 2012; Jing \& Van de Ven, 2013; Pan, Rowney, \& Peterson, 2012). Cross-cultural studies mobilize Western concepts, rationality, and methodologies to understand foreign phenomenon. They adopt an implicit ethnocentrism at an assumption level. This is true even in Westernbased Asian studies (Li, Leung, Chen, \& Luo, 2012; Tsui, 2007), and in HRM (Warner \& Zhu, 2002; Yang, 2012; Zhang, 2012).

\section{METHODOLOGY: USING JULLIEN'S DIALOGUE BETWEEN GHINA AND THE WEST}

Traditional Chinese thought is nurtured by different schools (Chen \& Lee, 2008) but written in one language. Jullien has been deconstructing Western ways of thinking by using texts and commentaries of different schools of Chinese tradition as a springboard to question Western thought. Defining research as an effort at discovery (rather than an effort to confirm hypotheses) brings us closer to the unknown, so that we may return to the known with an enriched perspective (Rappin, 2008). To use Jullien's approach to understand human potential and HRM implications we need to examine the dialogue between East and West, and Jullien's key philosophical concepts.

\section{Toward an Authentic and Intelligent Dialogue Between West and East}

An intelligent dialogue can begin with decoding some aspects of Chinese meaning of the world of philosophy (Jullien, 2000) and its applications to management (Chia, 2013, 2014; Fang, 2012; Shrivastava \& Persson, 2014). Jullien is interested in Chinese thought as a tradition: 'A tradition is precisely perceived from outside' (Mélès, 2009: 3). Cultural generalizations tend to be dangerous even if necessary (Fang, 2012; Xing, 1995; Yang, 2012). For Jullien, decoding the Chinese meaning of the world does not mean to state the historic or current 'truth' of Chinese culture (e.g., as studied by Pan et al. [2012] for business employees).

Decoding is a methodological lever for questioning the general framework of Western rationality as being universally or at least dominantly appropriate for the whole world. China offers 'a possible alternative to our Western philosophical preconceptions' (Jullien, 1999: 17). We have inherited these preconceptions and are 
now unable to think outside of them. Jullien creates a space of mutual inquiry that maintains the integrity and the richness of both Eastern and Western schools of thought.

We must clarify at the outset that neither Jullien's work, nor our application of it to HRD, implies that the West should follow the East, or that modern China offers a model to be emulated for sustainable HRM. On the contrary, we accept that traditional Chinese thought has only partly influenced modern Chinese practices in this area (Fang, 2012; Li et al., 2012; Warner, 2011; Yang, 2012; Zhang, 2012). We are also aware of the huge sustainability and human rights challenges facing modern China (Diener \& Rowe, 2007). We are using Chinese traditional thought not because it is uniform, but because it is culturally far from the West, and thus as a theoretical distancing methodological device within the method of deconstruction.

\section{Key Concepts in Traditional Chinese Thought}

With the concept of 'silent transformations' Jullien (2011a) specifically examines the erosive effects of time on life. He invites us to think of maturation and deterioration: aging, wearing, and global warming are considered as silent transformations that flee our attention. We become aware of these silent transformations only when an 'event' takes place. In the West, events fill time and introduce ruptures: 'The event is not simply what monopolizes the attention; it also structures the narrative and serves its dramatization' (Jullien, 2011 a: 121). The result of a silent transformation is generally presented as an event. In fact, this event is just an obvious part of a continuous process, which ceases to end. Through the Chinese lenses the different crises we know are merely 'sound outcrops' of silent, invisible, and underground transformations.

Chinese thought of alternation relates to any existence and any reality. What disappears does not necessarily mean it is eliminated; instead it signifies potentiality or latency. The separation between the visible and invisible does not exist. The invisible proceeds from the course of the world and not from a mystical spiritualism. There is neither a goal to reach nor a supreme purpose, such as 'happiness' (Jullien, 2007).

Table 1 introduces specific contrasts between two ways of thinking rooted in Western and Chinese thoughts and languages. It opens a space for dialogue between two cultures without pretending to compare cultural identities, a notion (cultural identity) that Jullien (2014, Chapter 13) distrusts. The concept of identity is premised on the ontological Western assumption that things have a nature by themselves because of their specific substance or essence. This is especially true for the human subject who exists as far as (s)he thinks ('I think therefore I am' for Descartes). It is true for phenomenology as well, with the 'being-in-the-world' which provides meaning to the world. This notion of identity linked to the issue of subjectivity questioned by Mélès (2009) does not exist in traditional Chinese thought since each 
Table 1. Contrast between the West and China

\begin{tabular}{|c|c|c|}
\hline & West & China \\
\hline $\begin{array}{l}\text { Strategy of meaning } \\
\quad \text { (Jullien, 2000, 2011a) }\end{array}$ & $\begin{array}{l}\text { Time is linear } \\
\text { The quest for eternity of the soul out } \\
\text { of time } \\
\text { A separation between theory and } \\
\text { practice } \\
\text { Knowledge and modelization }\end{array}$ & $\begin{array}{l}\text { Time is circular } \\
\text { A matter of season with the } \\
\text { natural renewal } \\
\text { Integration of theory and practice } \\
\text { Wisdom and ripening }\end{array}$ \\
\hline $\begin{array}{l}\text { Conception of human } \\
\text { being (Jullien, 2007, } \\
2011 \text { b) }\end{array}$ & $\begin{array}{l}\text { Human beings are subjects able to } \\
\text { read the world } \\
\text { Courage is a part of the heroic } \\
\text { personality } \\
\text { Willingness and effort are requested } \\
\text { Ontology: The soul and the meaning } \\
\text { Existing }\end{array}$ & $\begin{array}{l}\text { Human beings are within the } \\
\text { world } \\
\text { Courage is circumstantial } \\
\text { The body/mind within the } \\
\text { experience } \\
\text { Living Growth is a natural process }\end{array}$ \\
\hline $\begin{array}{l}\text { Idea of efficacy (Jullien, } \\
\text { 1999, 2000, 2004) }\end{array}$ & $\begin{array}{l}\text { Action } \\
\text { (cause } \rightarrow \text { effect } \rightarrow \text { cause) } \\
\text { Visible and direct } \\
\text { The potential is in the (human) } \\
\quad \text { subject } \\
\text { Model to follow, direct action } \\
\text { Projection and planning } \\
\text { To strengthen the nature }\end{array}$ & $\begin{array}{l}\text { Ripening, transformation } \\
\text { (conditions - consequences) } \\
\text { Invisible and indirect } \\
\text { The potential is in the situation } \\
\text { Anticipation, non-action } \\
\text { Continuing process } \\
\text { To espouse, to accompany the real }\end{array}$ \\
\hline
\end{tabular}

individual is in constant relation with his/her human and non-human environments in the world.

Table 1 avoids the implicit concession to the Western model of thinking based on definition and categorization. The price to pay is a less clear dividing line between categories which remain general ('allusive') here, in order to favor 'the deviations from Western tradition' (Jullien 2001: 369). In order to keep the dialogue open between Chinese and Western cultures, we offer indications of meaning more than strict definitions. Thus, we do not lose sight of the big picture as advocated by Tayeb (2001) and Yang (2012).

\section{JULLIEN'S CONGEPTS FOR HRD: EFFICAGY, FEEDING LIFE, AND THE GARDENING METAPHOR}

If we are to avoid Western isolation of HRM, we need to acknowledge the Eastern alternatives. An intelligent dialogue between cultures (Jullien, 2014) invites HRM to meet another reading of efficacy (Jullien, 1999, 2004) and also to integrate the process of 'vital nourishment' (Jullien, 2007) especially in dealing with stress at work. Such a dialogue can shape other kinds of organizational behavior and human relations at work. It can result in one that focuses on efficacy/propensity and feeding life instead of focusing on classical topics such as leadership, motivation, and engagement in action anchored in the Western thinking. 


\section{Efficacy in Western and Ghinese Thinking}

Economic growth is faced with global environmental and social challenges, particularly in China (Shrivastava, 2006; Warner, 2011; Zhang, 2012). Usual forms of growth based models, based on increasing economic productivity and efficacy (imported from the West) are facing ecological limits. Therefore, it is useful to examine relevant insights about efficacy (see last part of Table 1) offered by Chinese tradition. Jullien's analysis of this concept is now recognized and is of particular interest for strategy and management (Aligica, 2007; Chia, 2013; Shrivastava \& Persson, 2014).

Jullien challenges the very foundations of the way the West thinks about efficacy and strategy by opening new intellectual horizons (Aligica, 2007). Three of his books are focused on these themes (Jullien, 1999, 2000, 2004). Efficacy in Chinese tradition, especially through Daoism and the school of the Art of War (Chen \& Lee, 2008) is not linked to the cult of action (heroic or tragic), as it is in Greek inspired Western thought (Shrivastava \& Persson, 2014). Instead, efficacy is an aspect of the continuous process of transformation (Jullien, 1999, 2004, 2009). In the West, action is perceived, it is visible, one speaks about it; it creates the epics of yesterday and the events of today. However, in the traditional Chinese language there is no word for 'action' (Jullien, 2004, Chapter 4). Chinese thought, especially through Daoism (Lee et al., 2008) invites 'nonaction' which is often misunderstood by the West as 'inaction'. Let us specify the difference: Non-action or non-doing is still a form of action - that of effortless but deliberate alignment with natural flow of the elemental cycles; whereas inaction is inhibition to act. Thus efficacy involves enabling a flow of transformation so it is shaped in desired ways. The precept of non-action does not lead to disengagement. On the contrary, it teaches one how to succeed (Jullien, 2004: 85). Human intervention is thought of as indirect and oblique, not direct and frontal as it is in the West (Jullien, 2000).

In the West, efficacy is principally conceived as an action that is visible. It is positioned between a point of departure and a point of arrival - output over input. It is temporally identifiable and observable. It is about being direct - it uses direct means to arrive at its destination/goals. Action also implies forcing or compelling, thereby automatically producing a counter effect, or resistance (Jullien, 1999, 2004). In Chinese tradition, efficacy is conceived differently, as a potential, 'namely, the kind of potential that originates not in human initiative but instead results from the very disposition of things' (Jullien, 1999: 13).

Using the Chinese term 'shi', Jullien (1999) clarifies what he calls 'the propensity of things'. In Chinese, each character has an individual story (Wenzel, 2010: 470). Jullien (1999: 267) explains the term shi (勢), is the same as the word yi, it represents a hand holding something (probably a clod of earth, according to Xu Shen). This holding is a symbol of power, because it could symbolize something being put into position. The diacritic radical for force ( $l i$ 力) was later added. The spatial connotation of the word shi (時) corresponds with its temporal associations in the 
sense of 'opportunity' or 'chance'. The latter term is sometimes used in place of the former. The polysemy of the term 'shi' is indicative of the disposition of things between the static and the dynamic. Therefore, there is a confusing ambiguity (for the Western mind) in the word shi that carries different significations: 'position', 'circumstances', 'power', and 'potential' (Jullien, 1999: 12). For Jing and Van de Ven (2014) the term shi is better translated as momentum than as situation. In their Ying-Yang model, they refer to shi as situational momentum.

Instead of mobilizing action and the will of the actors like in the West, efficacy waits for available potential in all situations. What is important is to do the little something, which is needed in the current situation to get a strategic effect. These 'proactive small actions' (Chen \& Lee, 2008: 21) are very different from the spectacular actions of the leader in the West (Chia, 2013). They require perception of 'holistic insights or foresights into the hidden, underlying forces of the situation' (Chen \& Lee, 2008: 21). Small actions 'make subsequent drastic action unnecessary'. The most important driver of change is already embodied in the situation through the propensity of things (Jullien, 1999). For that reason, nonaction is a form of acting: 'do nothing, and let nothing be left undone' (Jullien, 2004: 85). The word 'and' in the previous quotation must also be understood in the double meaning so that/but. This paradoxical construction (and $=$ so that + but) is necessary to explain the nature of the conjunction between two apparently opposite ideas in European languages.

In Confucianism 'Being' comes before 'Doing' and ignores 'Thinking' (Yang, 2012: 168 \& 170). By decentralizing 'action’ this approach displaces an entire suite of Western social and organizational concepts such as 'agency' for action, leadership (leading action), and teamwork (collective action). It valorizes the natural flow of transformation, the role of natural and social environments. Lee et al. (2008) explain that, in the opinion of Laozi and many others Daoists, leaders are actually no more than servants or followers.

\section{To Feed One's Life Against Stress at Work}

Stress in organizations has grown uncontrollably for decades $(\mathrm{Lu}, \mathrm{Kao}, \mathrm{Siu}, \& \mathrm{Lu}$, 2011) to the level that it now paralyzes our vitality (Jullien, 2007). Many figures measure the increasing cost of physical and mental stress at work at the social and economic level in developing countries (Houtman et al., 2007; WFMH, 2012). Underestimating the link between stress and performance is especially criticized in the Critical Management Studies literature (Dany, 2009) and also by practitioners (Ho, 2009). The awareness of stress at work as linked to management of human resources is especially rising in the developing countries (Houtman et al., 2007). While most of the studies consider personal variables as individual differences, a few are beginning to consider cultural aspects. Lu et al. (2011) studied Chinese regional work values linked to Confucian traditions and their links to well-being at work. Even these studies do not consider the common nature of human beings in 
nature as advocated by Morin (1992). Stress is a natural and physical process of adaptation linked to life (Selye, 1956).

For Jullien (2007: 8), 'to feed one's life' is a very common Chinese expression that deserves our attention for facing increasing stress. By embodying this in his work, he is mindful of the lifespan development of Body-Mind-Spirit (Hwang, 2012). Jullien locates the question of how to feed life or nourish it in the Zhuangzi (third and fourth Century BCE). It could be a viable replacement of the ideal Western concept of 'happiness'.

Two points have to be emphasized here, because they are really provocative for Western philosophy. First, it is difficult to talk about this exemption from happiness with Western scholars. For many philosophers happiness appears as 'an unquestioned universal goal' (Jullien, 2007: 101). Second, Jullien's study is not only philosophical; he is also interested in fruitful guidelines for living. This is particularly important in the context of work life at a time when work has become a major source of stress with increasing social, institutional, and personal costs (Houtman et al., 2007).

Jullien (2007) proposes the expression 'vital nourishment' to translate the Daoist wisdom of living. This notion eludes the great divide between body and soul anchored in the West. Most Western philosophers since Plato prefer to emphasize thinking over experiencing life. They did not develop a theory of breath or life energy. Human self-fulfilment is conceived differently in China, as longevity and health are closely associated with fulfilment. Then the longevity of the body is a sign of nourishment of life and not a sign of impotence or decrepitude. Health is thought of as a regulation, not as a rule, like a process instead of a state (or shape). The Chinese verb (sheng) has multiple meanings, including, live well, be born, and procreate (Jullien, 2007: 128).

'Feeding' is not only a primordial activity that links us to the earth, but also links us to all other living things. In feeding, lies the core logic of sustainability. When Plato speaks about feeding the soul, he inverts the natural direction from terrestrial to celestial. Actually, Plato considers heaven/sky (the soul, God, truth, and transcendent knowledge) as superior to the earth (body, human, experience, and immanence of living). By considering rationality before vitality, he opened the way for Aristotle and thereafter for Descartes to abstract the self out of living. The economic and ethical questions about the care of the self (well-being) appear to be an intercultural issue, which has matured between saving one's soul (in the West) to safeguarding one's vitality (in China). For the latter, what matters is long life more than eternal life (Jullien, 2007).

Jullien (2007) analyses the Western pursuit of happiness as coupled with an uncontrollably growing counter effect - stress. Stress is increasingly present at work within organizations and in life outside of them. Stress is a generalized syndrome that crosses the boundaries of disciplinary knowledge: psychology, physiology, neurochemistry, sociology, and so on. The separation of the psychic and the somatic is no more tenable. Excessive pressures from the world and from within ourselves 
cause stress to turn into inner tension. Excessive stimulation also leads to stress that reduces our vitality. Jullien explains how the cliché 'be Zen' (as a Western importation of the anti-stress Chinese culture) is counterproductive. 'Zen can be achieved... only by abandoning the quest and the goal of being Zen' (Jullien, 2007: 141). An 'unfettered evolution' becomes possible only by avoiding the imperative mode and allowing 'a release from meaning (dogma, belief, truth)' (Jullien, 2007: 140).

Zhang, Chen, Liu, and Liu (2008) identify the sources of Western and Chinese philosophy that Chinese leaders use. They suggest management scholars should learn Chinese history and culture, especially because 'Western practices usually place high levels of stress on workers and make them estranged from the organization' (Zhang et al., 2008: 268). They find Chinese leaders, especially those inspired by Confucian thinking, valuing people more. Despite the success of famous books and executive MBA programs imported from the West, the Chinese leaders interviewed by Zhang et al. (2008: 269) 'have obtained only very limited insights from many Western management theories and business cases'.

The Chinese process of 'conditions - consequences' rather than the scientific Western causality 'cause 00E0 effect 00E0 cause' (Table 1), can help us renew the idea of human success as a mix of strategy and vital nourishment: 'Success is in the nature not of a goal achieved but of a result, like the dropping of a ripe fruit' (Jullien, 2007: 108). This core notion of 'ripening' as a silent and invisible transformation acts as a lever within the context of the gardening metaphor. Human potential is then grounded in 'a thought of life' (Jullien, 201 la: 93).

\section{The Gardening Metaphor for Managing Human Potential}

Vitalism as opposed to rationalism privileges the stretching of life, which is constantly moving and transforming (Rappin, 2008). In this sense, the Chinese living-oriented vitalism is an appropriate paradigm for understanding human sustainability from a holistic perspective. To transpose the contributions of Chinese thought and to give it an operational range for HRD, we suggest an organic metaphor of gardening. The metaphor is both wise and strategic because it actualizes the resulting potential from human resources being perceived as natural resources. It represents a shift from efficacy to efficiency.

Jullien (2004: 120) contrasts efficacy and efficiency. Efficacy posits an obligation to produce required results. Efficiency is working towards results with the minimum amount of expenditure (of time, money, effort, etc.). This disconnecting efficacy from plans, and goals, opens it up to a nature's autonomous logic of growth. 'Another way of conceiving efficacy is not to reconfigure the situation in an ideal way, in which a plan is made and an aim set up, but to ripen the conditions encountered, even the very ones in which one is oneself implicated' (Jullien, 2011a: 150). This quote is a relevant introduction to the gardening metaphor because it focuses on maturation as a ripening of any kind of situation ('to ripen the conditions encountered'). It 
highlights 'the propensity at work in reality' (Jullien, 1999, Chapter 10). It offers a radical contrast to the Western idea that causality is central to understanding.

In the West, 'it is by going back into the causes of things that we apprehend reality and its underlying principles' (Jullien, 1999: 219). For Kant (1724-1804, the great German philosopher), causality was a general law of understanding, a priori law (Jullien, 1999: 220). However, this is not true for Daoism in its interpretation of nature. When development is thought of as ripening, it becomes an autonomous growing process linked with the strength of life. The gardener welcomes this strength to make it evolve. Gardening makes use of the land. It involves sowing or planting when the season is ready and when the weather is favorable, digging and watering when necessary, and harvesting when maturity has been reached. In gardening the potential rests in the eventual growth of seeds, which are sown and transformed into young shoots or sprouts. Growth is a natural phenomenon (as are maturity and death). It constitutes an autonomous process in itself, a 'silent transformation' (Jullien, 2011a, 2004: 79). No belief, ideal, or virtue is involved in the process of natural growing of seeds. At the same time, the growth of roots depends equally on the circumstances, notably the climate, the land, the sun and also, of course, the work of the gardener in the form of indirect but facilitative intervention. The gardener knows it would be senseless to plant in the summer and harvest in the winter or to pull on the sprouts to make them grow faster.

Gardening obeys practical reason which consists of 'adapting to the propensity at work so as to be carried along by it and exploit it' (Jullien, 1999: 263). This definition of practical reason differs from the theoretical 'logic of practice' (Sandberg $\&$ Tsoukas, 2011). The division between practice and theory anchored in the antic Greek philosophy (Table 1) does not exist in China. Practical reason is not a question of logic, but a strategic recognition of the propensity at work (Chia, 2013; Shrivastava \& Persson, 2014). The gardener has a role to support the growth of roots and their maturing process. $\mathrm{S}(\mathrm{he})$ seeks favorable conditions. (S)he accommodates and looks after the land without directly acting on the growth of the plants.

Gardening assumes a confident and vigilant stance close to a posture of professional accompaniment (Paul, 2004). The growing of seeds (which represents human resource development) is taken for granted as a natural phenomenon. Circumstances (weather, sky, temperature which represent the environment of organizational life) are supervised in order to keep a close eye on the situation. Confidence and vigilance represent the two facets of a unique perspective, one that is a mix of observation, attention and care. This caring attitude brings attention to local context (Johns, 2006), place-based enterprise (Shrivastava \& Kennelli, 2013), popular culture (Bruner, 1990), and moreover ordinary routines (March, 1981). As underlined by Chia (2014: 23) from Jullien (2004: 19), 'with very little effort' one can nevertheless attain 'great effects' because 'ordinary action can lead to extraordinary outcomes' (Chia, 2014: 22). For HRD, these effects are the growth of human resources in a process of transformation through different cycles of life, respecting the lifespan development of the body-mind-spirit (Hwang, 2012: 37). 
As Jullien (2004:104) quotes: 'The notion of effectiveness should not be confined to purely technical domains'. "Effectivity" sounds like "affectivity" (Jullien 2004: 121). Effectivity is working in the Chinese sensibility (and produces effects), as affectivity is working in the Western sensibility (and produces affects). To know 'how' and 'what' is more important in Chinese thought, than to know 'why' and 'who', echoing the recent special issue of Management and Organization Review (Li et al., 2012). The gardening metaphor calls for a shift from wilful efficacy to natural efficiency (Jullien, 2004). The key issue for HRM questions the conditions for effectiveness, as opposed to 'efficacy'.

Jullien's efficiency is not the narrow input/output ratio commonly called efficiency in the West. Instead efficiency emerges from a 'humanity fund' echoing the Confucian philosophy of benevolence (ren) (Yang, Peng, \& Lee, 2008). This humanity fund does not respect a priori principle of equity just anchored at a mental level (as advocated by Kant) but emerges from within as a natural and powerful process which embraces the whole of humanity (Jullien, 1995). A natural pity as a latent and a posteriori re-action (more than a moral and a priori action) is at the same time an 'affect' and an 'effect' (without intentionality) (Jullien, 2004: 121). That is why the virtue of humanity is capable of effectiveness. It proceeds from a sustainable humanity fund of effects and witnesses the entanglement of humans.

Gardening provides an expressive metaphor for modeling the disposition of HRD as a process of caring accompaniment. Human development at work is then based on the natural and collective potential of the HR garden. The very idea of potential must be understood not as 'a potential for', but as 'an absolute potential' (Jullien, 2004: vii), upstream, 'before reality is yet actualized' (125). Management has to tend to the garden (the workplace, organizational life, physical spaces and interactions between people at work).

\section{GREEN AND GOMPASSIONATE AVENUES FOR HRM RESEARGH}

The word 'green' is commonly linked to the idea of the natural environment. HRM can be 'greened' by categorizing the HRD process from the beginning to the end of professional life within a company (Renwick, Redman, \& Maguire, 2008: 101). The life cycle of HR consists of different stages: birth through the recruitment process, growth through people development, climate through social relations, and death through redundancy, departure or retirement. Mainstream HR research can invest in this encompassing ecological stance, go beyond its two traditional core concerns of efficacy (productivity) and employee development (Gardner \& Wright, 2009), by drawing foundations of Chinese psychology (Hwang, 2012) especially respecting the body-mind-spirit model (Chen \& Bhikkhu, 2003).

These points are developed as follows: first we offer ordinary questions to link the green metaphor to the gardening of $\mathrm{HR}$, second we propose greening the dialogue between the West and China by binding pragmatism and compassion, and third, we invite HRM scholarship to enter in a green reflexivity. 


\section{A Green Metaphor to Better Question HRD}

The gardening metaphor is eco-friendly, contextualized in natural systems, and based on values of caring, nurturing, and stewardship. This metaphor speaks both to Chinese and Western cultures. It goes beyond 'theoretical' distinctions (which are based in Western thought) and away from convergence or divergence perspectives (Fang, 2012; Warner, 2009). For the convergence perspective, HRM principles and practices can be generalized in China; for the divergence perspective, context-specific theories and practices of HRM should be used (Zhang, 2012). The gardening metaphor suggests a third possibility: bounded or relative convergence. It evokes simultaneously 'very realistic and holistic approach' echoing Sun Tzu strategy (Chen \& Lee, 2008: 21). Second it just needs 'proactive small action' (Chen \& Lee, 2008: 21) to accompany and sustain the natural growth (of HR). Third, it mediates between Heaven and Earth where the Confucian mind of benevolence (Hwang, 2012: 107) echoes the idea of Western humanism.

The gardening metaphor evokes discussions of knowledge and sensitivity, and lends itself to three key topics of research for sustainable HRD within a company: recruitment, people development and social relations. These topics are well recognized by HRM and impact organizational behaviours. They also bring together an on-going cyclical process: birth, development, maintenance, death. We acknowledge that our analysis here does not cover the complete cycle. Particularly, we avoid embracing the question of death at this stage. Death is a sensitive issue in the West (Weber, 2013) that valorises the 'existing' over the 'living' (see Human being in Table 1). We acknowledge that issues of maturity, decline, and death of human potential, need more development.

At this current stage of research we can absorb some insights from the gardening metaphor for HRD by echoing Jullien's (2011a: 148) question: 'As a descriptive concept, could the silent transformation become an art of managing'? Table 2 addresses this question by aligning three key HRD/HRM practices (recruitment, development and social relations) with the gardening stance, the context of managing, and the potential fund of effects:

1. The very stance of gardening, adopting a posture of accompaniment (Paul, 2004), respects the 'practical reason or wisdom mostly evolved from the Taoist, Confucian and Buddhist thought' (Hwang, 2012: 47).

2. Taking the full context into account requires context-sensitive scholarship (Tsui, 2013). Context is not recognized enough or appreciated in organizational behavior research (Johns, 2006: 389). It echoes the 'place-based enterprise' developed by Shrivastava \& Kennelly (2013: 86) who argue that sustainability is best understood in terms of its rootedness in place.

3. Looking for the potential 'fund of effects' before reality is actualized (Jullien, 2004: 125), allows better anticipation. What matters is 
Table 2. Questioning three research topics in HRM

\begin{tabular}{|c|c|c|c|}
\hline & Recruitment & People Development & Social relations \\
\hline Gardening & $\begin{array}{l}\text { How does } \\
\text { transplantation work? } \\
\text { How can the risks of } \\
\text { rejection be avoided? } \\
\text { How can one take } \\
\text { advantage of the 'herd } \\
\text { instinct'? }\end{array}$ & $\begin{array}{l}\text { What are the 'vital } \\
\text { nourishments' for } \\
\text { people? How can tacit } \\
\text { knowledge be } \\
\text { transferred between } \\
\text { people? Which season } \\
\text { is best for planting and } \\
\text { for harvesting? }\end{array}$ & $\begin{array}{l}\text { How to favor a healthy } \\
\text { social climate? What are } \\
\text { better conditions to } \\
\text { generate convenient } \\
\text { consequences? Which } \\
\text { accommodation should } \\
\text { be made to nourish social } \\
\text { relations? }\end{array}$ \\
\hline $\begin{array}{l}\text { Context } \\
\text { Time - Space }\end{array}$ & $\begin{array}{l}\text { Internal or external } \\
\text { recruitment? } \\
\text { Cooptation or } \\
\text { selection? How to } \\
\text { associate the } \\
\text { concerned team with } \\
\text { the recruitment } \\
\text { process? How tacit } \\
\text { knowledge carries } \\
\text { potential? What are } \\
\text { required forms of } \\
\text { intelligence? }\end{array}$ & $\begin{array}{l}\text { What is a safe place for } \\
\text { learning by 'living'? } \\
\text { What are informal } \\
\text { practices of } \\
\text { accompaniment, } \\
\text { which act without } \\
\text { taking action? How to } \\
\text { find the adapted rate } \\
\text { as a sustainable } \\
\text { rhythm? Which kind } \\
\text { of accompaniment is } \\
\text { good for growth and } \\
\text { for decrease? How to } \\
\text { favour peer relations? }\end{array}$ & $\begin{array}{l}\text { What kind of physical space } \\
\text { to encounter, negotiate? } \\
\text { How much time and } \\
\text { which rhythm to sustain } \\
\text { relations? Which } \\
\text { regularity to afford the } \\
\text { change and tame the } \\
\text { opponent? How to make } \\
\text { a break and when? } \\
\text { Which stakes for time } \\
\text { work, full or part time } \\
\text { employment? }\end{array}$ \\
\hline $\begin{array}{c}\text { The fund of } \\
\text { effects }\end{array}$ & $\begin{array}{l}\text { What kind of integration } \\
\text { between formal and } \\
\text { informal, individual } \\
\text { and collective? How a } \\
\text { career becomes a } \\
\text { consequence more } \\
\text { than a purpose? What } \\
\text { are the silent } \\
\text { transformations in } \\
\text { psychological } \\
\text { contracts? }\end{array}$ & $\begin{array}{l}\text { How to make most use } \\
\text { of ageing of } \\
\text { employees? What are } \\
\text { the different potentials } \\
\text { of the seasons of adult } \\
\text { life? How to mobilize } \\
\text { stress without creating } \\
\text { burn-out? What are } \\
\text { impacts of work-life } \\
\text { balance? }\end{array}$ & $\begin{array}{l}\text { How to take care of } \\
\text { opponents to gain } \\
\text { ground? Which alliances } \\
\text { (internal and external) } \\
\text { are needed to sustain the } \\
\text { company? How to lose a } \\
\text { bit to keep a relationship } \\
\text { alive? How to participate } \\
\text { in the storytelling of the } \\
\text { social relation without } \\
\text { ending? }\end{array}$ \\
\hline
\end{tabular}

See Appendix I with examples (Bae \& Rowley, 2001; Danford \& Zhao, 2012; Zhang, 2012)

to think about potential contextual influences without isolating or prioritising some features a priori. Researchers need to avoid the usual reductionism of publications-motivated research (Tsui, 2013: 386).

Table 2 focuses on an array of questions which are involved in the daily life of HRD professionals. Moreover, when a set of HRM practices is internally aligned, it forms a bundle of practices that operate in concert with each other (Jackson \& Seo, 2010). This alignment can facilitate intervening subtly to inflect the situation beforehand at the level of conditions. This upstream intervention could preclude the need for spectacular heroic leadership action later (Jullien, $2011 \mathrm{a}$ : 156). This opens a major invitation to engaged HRM scholarship. As noted by Jackson et al. (2011: 111-112) not all HR professionals agree that the future belongs to green HRM. 
Studies indicate that HRM systems around the world are becoming more and more similar. To reduce the homogeneous use of North American models in (Asiatic) management studies (Li et al., 2012; Tsui, 2007, 2013), our major invitation for HRM scholarship is to cross boundaries between professionals and scholars, between ways of thinking, and between disciplines (Jackson et al., 2011).

\section{Pragmatism and Compassion}

HRD dialogue needs to be pragmatic, looking for intelligibility between actors, and rooted in compassion more than in an incantatory quest for truth, justice, or absolute meaning. Western implementation of compassion manifested in the Universal Declaration of Human Rights (which is an inspiration for numerous Corporate Social Responsibility policies) is built on a belief in the superiority of the West and its values. Beyond the manifest text of the declaration, the West does little to implement Human Rights policies, because it is very difficult economically, and because they are historically contingent in each country. In the context of globalization, Jullien (2014) problematizes the concept of 'universal' by specifying the conceptual differences between 'universal' (philosophy oriented), 'uniform' (economics oriented standardization) and 'common' (politics oriented - shared). Uniformity in the ways of life is adopted in the West for economic purposes. Management practices do not need to become uniform globally (Li et al., 2012). Instead they should consider a common array of upstream issues. These include the best conditions and processes for nurturing (gardening) HR in the context of their unique environments (climate, weather, culture, sector, etc.).

Even if the scale of value is increasingly 'uniform' value of production, it is not a 'universal' value in a moral sense (Jullien, 2014). The refusal advocated by Jullien arises in fact from a collective tacit knowledge primarily anchored in human beings. If we consider the tacit more than the explicit knowledge in the declaration of human rights, we discover an underground but efficient potential that frames a direction to follow. It is a direction that does not pretend how to act for governing/managing people, but indicates what should be avoided - the unbearable, the cruel. It is not anchored in a normative and explicitly Western conception of morality, but instead emerges from human entanglement as illustrated by Mencius, a symbol of Chinese morality in Confucianism (Hwang, 2012; Yang et al., 2008).

The notion of entanglement (between humans and their environments) is more salient in Chinese culture and impacts HRD by going beyond individualization and autonomy. Confucian tradition especially accepts the notion of destiny of the biological being (birth, aging, disease, death) added to conscience and selfawareness (Hwang, 2012: 102). The awareness of entanglement of humans in nature and culture allows a better perception of contingent situations and their mutual interests in a long-term perspective (Table 2). It calls for developing collaboration at work, specifically through social relations - by taking care of the opponents during a rough negotiation for instance, in order to keep a sustainable relationship 
(column 3). It then allows people development conceived as an accompaniment (column 2) through daily management of sustainable and compassionate leaders (Boyatzis, Smith, \& Blaize, 2006). Such leaders practice team coaching as a core function of their activity (Hackmann \& Wagemann, 2005). It favors sustainable networking where Chinese are gifted within their cultural guanxi (Chen \& Chen, 2004; Chen, Chen, \& Huang, 2013) and favors all the cycles of life of HR from recruitment to departure (Column 1). The concept of guanxi is central to understanding social behavior in Chinese society (Hwang, 2012: 297). Guanxi practices are used to establish interpersonal trust, in a process of relationship changes that go from instrumental ties, to mixed ties, and then to expressive ties. They impact organizational behaviors in Chinese society (Hwang, 2012, Chapter 11).

\section{Toward Reflexivity/Reflection for Engaged HRM Scholarship}

Reflexivity strengthens the sensitivity of 'being affected' (Callon \& Rabeharisoa, 2004) as an aspect of 'being in phase' (Jullien, 2007) with the environment. Reflexivity as self-reflection of what it means to be humans in nature and in culture could favor a sustainable hygiene for greener HRD research. It recognizes the embodied dimension of organizational culture (Flores-Pereira, Davel, \& Cavedon, 2008). It deserves to enter management and organizational studies (Tsui, 2013) as an enquiry for 'critical performativity' (Spicer, Alvesson, \& Kärreman, 2009) especially for HRM (Jackson et al., 2011: 101) because there is very little academic production at the intersection of HRM and environmental management.

Researchers are invited to practice reflexivity to become more aware of the interests they serve. They need to consider their own political stance, their cultural anchoring, and their specific and relative voice (Alvesson, Hardy, \& Harley, 2008). Without such reflexivity we risk ignoring the silent transformations in organizations, in society, and in their environments. This reflexive turn involves new debates and modes of research especially for HRM (Janssens \& Steyaert, 2009). Research that questions ideological assumptions remains pragmatic, and aware of its anthropological roots in culture. The greening engagement of scholarship, moral or political, is not aimed at transcendence. The practitioner and the scholar are entwined in the same situation in which sustainability and compassion appear as a potential opportunity for scholarship directed towards the primary source of living in firms: its people.

\section{CONGLUSION}

By taking specifically into consideration François Jullien's work based on different schools of Chinese tradition, we question the deeply culture-centric HRM thinking from the West. Jullien's works are being mobilized in management studies, especially in strategy (Aligica, 2007; Chia, 2013; Shrivastava \& Persson, 
2014), organizational change (Chia, 2014) and organizational behavior (Persson, Wasieleski, 2015). In the emerging dialogue between the West and China, we propose a meta-theoretical perspective which shapes a living oriented vitalist paradigm for HRD. The Western design of efficacy is contrasted with the Chinese notion of potential, which is embedded in situations more than in the subject/individual. We propose a gardening metaphor for HRD, at a time where stress is recognized as a major hazard for organizations in the developing countries.

Today, Chinese corporations are rapidly growing, mimicking Western global companies. They have been learning how Western management leads from an economic and financial perspective. However, the question remains: will the West be able to learn from the traditional Chinese way of thinking and their common art of wisdom and war to nourish human potential within more ecocentric organizations? This question has to be taken into account especially by developing countries today to sustain HRD without continuing to increase stress at the workplace.

\section{NOTES}

We would like to thank Peter Ping Li and the anonymous reviewers for their help in improving this paper and Celio A. A. Sousa, Instituto Superior da Maia, Portugal; Andrew Ross and Tejaswinee Jhunjhunwala, David O'Brien Centre, Concordia University, Canada; Bertrand Agostini, ICN Business School, France; and Haiying Lin, University of Waterloo, Canada for their valuable comments on earlier versions of the enclosed paper.

\section{APPENDIX I}

Table 2 provides transdisciplinary research questions that HRD needs to address to become sustainable. Transdisciplinary methods allow for a questioning of the latent epistemology of knowledge while developing practical solutions to real world problems. Below, we identify three examples from the literature:

Danford and Zhao (2012) analyzed three auto plants in SOE (state owned enterprises) using a blend of Western and Confucian values linked practices. Workers were skeptical as to whether Confucianbased harmony can be effectively practiced in other state or private capitalistic workplaces where the conflict of class interests is endemic. Moreover, there may be other sources of worker discontent that go beyond particularities of employer controls, and have to do with the macro economic and political conditions.

Zhang (2012) studied companies like Lenovo, Formosa Plastics, Haier, Huawei Technology which have created hybrid HRM systems that combine Western and Confucian values. This has created paradoxes in management, but Chinese culture is particularly skilled in managing paradoxes. These companies have built an edge over their counterparts in China because they benefit from knowledge and experience of modern HRM in market economies while retaining some of their deep cultural values that facilitate business. They absorb new cultural elements in HRM practices that moderate some of the undesirable effects of Guanxi such as nepotism.

Bae and Rowley (2001) studied the impact of globalization on HRM in South Korean companies where Confucian values were likely to be found. Many successful Korean companies such as Samsung Electronics and Hyundai Electronics have established and maintained the family-based ideologies and rules, and have managed their employees as their family members, even when financial control was not in the family.

Going back to the wider human territory (and not treating humans as instruments of labour) is important to maintain a real dialogue with practitioners (Ho, 2009). The sustainability we are looking 
for is not only the sustainability of academic HRM, but sustainability of the discourse between scholarship and practice. Sustainable human and organizational behaviors emerge by engaging those who should know (the scholars) and those who should do (the practitioners).

\section{REFERENGES}

Abram, D. 1996. The spell of the sensuous: Perception and language in a more-thanhuman zorld. New York: Vintage Books.

Aligica, P. D. 2007. Efficacy East and West: François Jullien's explorations in strategy. Comparative Strategy, 26(4): 325-337.

Alvesson, M., Hardy, C., \& Harley, B. 2008. Reflecting on reflexivity: Reflexive textual practices in organization and management theory. Journal of Management Studies, 45(3): $480-501$.

Alvesson, M., \& Kärreman, D. 2000. Taking the linguistic turn in organizational research challenges, responses, consequences. The Journal of Applied Behavioral Science, 36(2): 136-158.

Bae, J., \& Rowley, C. 2001. The impact of globalization on HRM: The case of South Korea.Journal of World Business, 36(4): 402-428.

Becker, B. E., \& Gerhart, B. 1996. Human resources and organizational performance: Progress and prospects. Academy of Management Journal, 39(4): 779-801.

Bowen, D. E., \& Ostroff, C. 2004. Understanding HRM-Firm performance linkages: The role of the 'strength' of the HRM system. Academy of Management Revieze, 28(2): 203-221.

Bruner, J. 1990. Acts of meaning. Cambridge, MA: Harvard University Press.

Callon, M., \& Rabeharisoa, V. 2004. Gino's lesson on humanity: Genetics, mutual entanglements and the sociologist's role. Economy and Society, 33(1): 1-27.

Chen, C.-C., \& Lee, Y.-T. 2008. Introduction: The diversity and dynamism of Chinese philosophies on leadership. In C.-C. Chen \& Y.-T. Lee (Eds.) Leadership and management in Ghina: 1-27. Cambridge: Cambridge University Press.

Chen, G. C., Chen, X.-P., \& Huang, S. 2013. Chinese guanxi: An integrative review and new directions for future research. Management and Organization Revieze, 9(1): 167-207.

Chen, G. Y., \& Bhikkhu, H. M. 2003. A model of spiritual care for hospice. Conference on Functions of Religion in Psychological Rehabilitation after Disaster, Taipei, Taiwan.

Chen, M.-J., \& Miller, D. 2010. Exchange - West meets East towards an ambicultural approach to management. Academy of Management Perspectives, 24(4): 17-24.

Chen, M.-J., \& Miller, D. 2011. The relational perspective as a business mindset: Managerial implications for East and West. Academy of Management Perspectives, 25(3): 6-18.

Chen, X.-P., \& Chen, C. C. 2004. On the intricacies of Chinese guanxi: A process model of guanxi development. Asia Pacific Journal of Management, 21(3): 305-324.

Chia, R. 2013. In praise of strategic indirection: An essay on the efficacy of oblique ways of responding. Management, 16(5): 667-679. [Cited 15 March 2015.] Available from URL: http://www.management-aims.com/PapersMgmt/165Chia.pdf

Chia, R. 2014. Reflection: In praise of silent transformation - Allowing change through 'letting happen', Journal of Change Management, 14(1): 8-27.

Danford, A., \& Zhao, W. 2012. Confucian HRM or unitarism with Chinese characteristics? A study of worker attitudes to work reform and management in three state-owned enterprises. Work, Employment and Society, 26(5): 839-856.

Dany, F. 2009. Recherche critique en GRH et critique de la recherche : un voyage au cœur de la littérature qui met à mal certaines idées reçues. In D. Golsorkhi, I. Huault, \& B. Leca (Eds.), Les études critiques en management, une perspective française: $307-328$. Canada: Presses de l'Université Laval.

Delery, J. E., \& Doty, D. H. 1996. Modes of theorizing in strategic human resource management: Tests of universalistic, contingent and configurational performance predictions. Academy of Management Journal, 39(4): 802-835.

Diener, B., \& Rowe, A. 2007. China: The challenges of economic growth and environmental sustainability. Greener Management International, A Journal of Corporate Environmental Strategy and Practice, 50: 5-9.

Fang, T. 2012. Yin Yang: A new perspective on culture. Management and Organization Reviez, 8(1): 25-50. 
Flores-Pereira, M. T., Davel, E., \& Cavedon, N. R. 2008. Drinking beer and understanding organizational culture embodiment. Human Relations, 61(7): 1007-1026.

Godard, J., \& Delaney, J. T. 2003. Reflections on the 'high performance' paradigm's implications for industrial relations as a field. Industrial and Labor Relations Review, 53(3): 482-503.

Guest, D. E. 2007. Don't shoot the messenger: A wake-up call for academics. Academy of Management Journal, 50(5): 1020-1026.

Hackmann, J. R., \& Wagemann, R. 2005. A theory of team coaching. Academy of Management Revieze, 30(2): 269-287.

Hambrick, D. C. 1994. Presidential address: What if the Academy mattered? Academy of Management Revieze, 19(1): 11-18.

Ho, K. P. 2009. Curbing the rise of the Hero-CEO. The Straits Times. [Cited 15 March 2015.] Available from URL: http://www.smu.edu.sg/sites/default/files/smu/news_ room/smu_in_the_news/2009/sources/ST_20091118_1.pdf

Houtman, I., Jettinghoff, K., \& Cedillo, L. 2007. Raising awareness of stress at work in developing countries: A modern hazard in a traditional working environment, World Health Organization, Protecting Workers' Health Series No 6. [Cited 15 March 2015.] Available from URL: http://www.who.int/occupational_health/publications/raisingawarenessofstress.pdf?ua=1

Huselid, M. A. 1995. The impact of human resource management practices on turnover, productivity and corporate financial performance. Academy of Management Journal, 38(3): 635-672.

Hwang, K.-K. 2012. Foundations of Chinese psychology - Confucian social relations. New York: Springer.

IPCC (Intergovernmental Panel on Climate Change). 2007. Climate Change Synthesis Report: Summary for Policymakers, Geneva: Intergovernmental Panel on Climate Change. [Cited 15 March 2015.] Available from URL: http://www.ipcc.ch/pdf/assessment-report/ar4/syr/ar4_syr.pdf

Jackson, S. E., \& Seo, J. 2010. The greening of strategic HRM scholarship. Organization Management Journal, 7(4): 278-290.

Jackson, S. E., Renwick, D., Jabbour, C. J. C., \& Muller-Camen, M. 2011. State-of-the-art and future directions for green human resource management: Introduction to the special issue. Zeitschrift für Personalforschung, 25(2): 99-116.

Janssens, M., \& Steyaert, C. 2009. HRM and performance: A plea for reflexivity in HRM studies. Journal of Management Studies, 46(1): 143-155.

Jing, R., \& Van de Ven, A. H. 2014. A Yin-Yang model of organizational change: The case of Chengdu Bus Group. Management and Organization Revieze, 10(1): 29-54.

Johns, G. 2006. The essential impact of context on organizational behavior. Academy of Management Revieze, 31(2): 366-408.

Jullien, F. 1995. Fonder la morale Dialogue de Mencius avec un philosophe des Lumières. Paris: Grasset.

Jullien, F. 1999. The propensity of things toward an history of efficacy in China. New York: Zone Books, MIT Press.

Jullien, F. 2000. Detour and access: Strategies of meaning in Ghina and in Greece. New York: Zone Books.

Jullien, F. 2004. Treatise on efficacy: Between Western and Chinese thinking. Honolulu: University of Hawai'i Press.

Jullien, F. 2007. Vital nourishment departing from happiness. New York: Zone Books.

Jullien, F. 201 la. The silent transformations. London: Seagull.

Jullien, F. 201 1b. Philosophie du vivre. Paris: Gallimard.

Jullien, F. 2014. On the universal: The uniform, the common and dialogue between cultures. Cambridge: Polity Press.

Kabat-Zinn, J. 1990. Full catastrophe living: Using the wisdom of your body and mind to face stress, pain, and illness. New York: Delta Press.

Kilduff, M. 1993. Deconstructing organizations. Academy of Management Revieze, 18(1): $13-31$.

Lash, S. 2009. Afterword: In praise of the a posteriori sociology and the empirical. European Journal of Social Theory, 12(1): 175-187.

Lee, Y.-T., Han, A.-G., Byron, T. K., \& Fan, H.-X. 2008. Daoist leadership: Theory and application. In G.-C. Chen \& Y.-T. Lee (Eds.) Leadership and management in China: 83-107. Cambridge: Cambridge University Press.

Li, P. P., Leung, K., Chen, C. C., \& Luo, J.-D. 2012. Indigenous research on Chinese management: What and how. Management and Organization Revieze, 8(1): 7-24. 
Lu, L., Kao, S. F., Siu, O. L., \& Lu, C. Q. 2011. Work stress, Chinese work values, and work well-Being in the Greater China. The Journal of Social Psychology, 151(6): 767-783.

March, J. G. 1981. Footnotes to organizational change. Administrative Science Quarterly, 26(4): $563-577$.

Mélès, B. 2009. Experience and subjectivity: François Jullien and Jean-François Billeter. Personality and Subjectivity East and West, Université Blaise Pascal, ClermontFerrand, France, December 10-11. [Cited 15 March 2015.] Available from URL: http://baptiste.meles.free.fr/site/B.Meles-Experience_subjectivity.pdf

Morin, E. 1992. Method toward a study of humankind vol. 1 The nature of nature. New York: Peter Lang.

Pan, Y., Rowney, J. A., \& Peterson, M. F. 2012. The structure of Chinese cultural traditions: an empirical study of business employees in China. Management and Organization Revieze, 8(1): 77-95.

Paul, M. 2004. L'accompagnement une posture professionnelle spécifique. Paris: L'Harmattan.

Persson, S., \& Wasieleski, D. 2015. The seasons of the psychological contract. Human Resource Management Reviere, 25(4): 368-383.

Purser, R. E., Park, C., \& Montuori, A. 1995. Limits to anthropocentrism: Toward an ecocentric organization paradigm? Academy of Management Revieze, 20(4): 1053-1099.

Rappin, B. 2008. Herméneutique et sciences de gestion. Paris: L'Harmattan.

Renwick, D., Redman, T., \& Maguire, S. 2008. Green HRM: A review, process model, and research agenda. University of Sheffield Working Paper. [Cited 15 March 2015.] Available from URL: http://www.sheffield.ac.uk/content/1/c6/08/70/89/2008-01.pdf

Rockström, J., Steffen, W., Noone, K., Persson, Å., Chapin, F. S. III, Lambin, F. E., Lenton, T. M., Scheffer, M., Folke, C., Schellnhuber, H., Nykvist, B., De Wit, C., Hughes, T., Van der Leeuw, S., Rodhe, H., Sörlin, S., Snyder, P. K., Costanza, R., Svedin, U., Falkenmark, M., Karlberg, L., Corell, R. W., Fabry, V. J., Hansen, J., Walker, B., Liverman, D., Richardson, K., Crutzen, P., \& Foley, J. A. 2009. A safe operating space for humanity. Nature, 461: 472-475.

Rousseau, D. M. 2006. Is there such a thing as 'evidence-based management'? 2005 Presidential address. Academy of Management Revieze, 31(2): 256-269.

Rynes, S. 2007. Tackling the "great divide" between research production and dissemination in human resource management. Academy of Management Journal, 50(5): 985-986.

Rynes, S. L., Gulik, L., \& Brown, K. G. 2007. The very separate worlds of academic and practitioner periodicals in human resource management: Implications for evidence-based management. Academy of Management Journal, 50(5): 987-1008.

Sandberg, J., \& Tsoukas, H. 2011. Grasping the logic of practice: Theorizing through practical rationality. Academy of Management Revieze, 36(2): 338-360.

Selye, H. 1956. The stress of life. New York: McGraw-Hill.

Shrivastava, P., \& Kennelly, J.J. 2013. Sustainability and placed-based enterprise. Organization and Environment, 26(1): 83-101.

Shrivastava, P. 2006. Sustainable transportation strategies: China. Green Management International, 50: 53-63.

Shrivastava, P., \& Persson, S. 2014. A theory of strategy - learning from China: From walking to sailing. Management, 17(1): 38-61. [Cited 15 March 2015.] Available from URL: http://www.management-aims.com/PapersMgmt/171Shrivastava.pdf

Schuler, R. S., \& Jackson, S. E. 2007. Strategic human resource management, 2nd ed. London: Blackwell.

Sims, D., Fineman, S., \& Gabriel, Y. 1990. Organizing and organizations. London: Sage.

Spicer, A., Alvesson, M., \& Kärreman, D. 2009. Critical performativity: The unfinished business of critical management studies. Human Relations, 62(4): 537-560.

Starkey, K., \& McKinley, , A. (Eds.) 1997. Foucault, management and organizational theory. London: Sage.

Stern, N. 2008. The economics of climate change. American Economic Reviezv: Papers \& Proceedings, 98(2): 1-37.

Steyaert, C. \& Janssens, M. 1999. Human and inhuman resource management: Saving the subject of HRM. Organization, 6(2), 181-198.

Tayeb, M. 2001. Conducting research across cultures: Overcoming drawbacks and obstacles. International Journal of Cross Cultural Management, 1(1): 91-108.

Townley, B. 1993. Foucault power/knowledge and its relevance for human resource management. Academy of Management Reviez, 18(3): 518-545. 
Tsoukas, H. 1994. New thinking in organizational behaviour. London: ButterworthHeinemann.

Tsui, A. S. 2007. From homogenization to pluralism: International management research in the academy and beyond. Academy of Management Journal, 50(6): 1353-1364.

Tsui, A. S. 2013. The spirit of science and socially responsible scholarship. Management and Organization Revieze, 9(3): 375-394

Van de Ven, A. H., \& Johnson, P. E. 2006. Knowledge for theory and practice. Academy of Management Revieze, 31(4): 802-821.

Warner, M. 2009. 'Making sense' of HRM in China: Setting the scene. International Journal of Human Resource Management, 20(11): 2169-2193.

Warner, M. 2011. Society and HRM in China. The International Journal of Human Resource Management, 22(16): 3223-3244.

Warner, M., \& Zhu, Y. 2002. Human resource management 'with Chinese characteristics': A comparative study of the Peoples Republic of China and Taiwan. Asia Pacific Business Revieze, 9(2): 21-42.

Weber, A. 2013. Enlivenment toward a fundamental shift in the concept of nature, culture and politics. Volume 31 of the Publication Series Ecology, Berlin: Heinrich Böll Stiftung.

Wenzel, G. H. 2010. Isolation and involvement: Wilhem von Humbold, François Jullien and more. Philosophy East and West, 60(4): 458-475.

WFMH (World Federation for Mental Health). 2012. Depression: A global crisis. World Mental Health Day, October 10.

Yang, B. 2012. Confucianism, socialism, and capitalism: A comparison of cultural ideologies and implied managerial philosophies and practices in P. R. China. Human Resource Management Revieze, 22(3): 165-178.

Yang, X.-P., Peng, Y.-Q., \& Lee, Y. -T. 2008. The Confucian and Mencian philosophy of benevolent leadership. In C.-C. Chen \& Y.-T. Lee (Eds.) Leadership and management in China: 31-50. Cambridge: Cambridge University Press.

Zhang, M. 2012. The development of human resource management in China: An overview. Human Resource Management Revieze, 22(3): 161-164.

Zhang, Z.-X., Chen, C. -C., Liu, L. A., \& Liu, X. -F. 2008. Chinese traditions and Western theories: Influences on business leaders in China. In C.-C. Chen \& Y.-T. Lee (Eds.) Leadership and management in China: 239-271. Cambridge: Cambridge University Press.

Sybille Persson (sybil.persson@icn-groupe.fr) is Professor of HRM at ICN Business School (Nancy, France) and a member of the CEREFIGE lab at the University of Lorraine where she received her PhD. She is also Head of the ICN School of Coaching for executives. She has opened an innovative track of research by studying François Jullien's works to identify the roots of the Western thought in management. She has published 3 books and 25 articles in scholarly journals.

Paul Shrivastava (paul.shri@gmail.com) is the Executive Director of Future Earth, and Professor of Management at Concordia University, Montreal. $\mathrm{He}$ received his $\mathrm{PhD}$ from the University of Pittsburgh. He was tenured Associate Professor of Management at NYU; Fulbright Senior Scholar at Kyoto University; Howard I. Scott Chair in Management at Bucknell University; and Director of the David O'Brien Centre for Sustainable Enterprise, Concordia University. He has published 17 books and over 100 articles in scholarly journals.

Manuscript received: December 13, 2013

Final version accepted: October 09, 2015 (number of revisions - 4)

Accepted by: $\quad$ Senior Editor Peter Ping Li 